\title{
Seed germination ecophysiology of the wild pineapple, Ananas ananassoides (Baker) L.B.Sm. (Bromeliaceae)
}

\author{
Fernando Augusto Oliveira Silveira ${ }^{1,3}$, Jean Carlos Santos² and Geraldo Wilson Fernandes
}

Recebido em 29/09/2009. Aceito em 14/07/2010

\begin{abstract}
RESUMO - (Ecofisiologia da germinação de sementes do ananás, Ananas ananassoides (Baker) L.B.Sm. (Bromeliaceae)). Neste estudo foram investigados os efeitos da luz, temperatura e armazenamento na germinação de sementes do ananás, Ananas ananassoides, uma bromélia de sub-bosque de cerradão. As sementes foram submetidas aos testes nas temperaturas de $15,20,25,30$ e $35^{\circ} \mathrm{C}$ em fotoperíodo de 12 horas e escuro contínuo por 30 dias. As sementes foram consideradas fotoblásticas e as temperaturas ótimas para germinação foram 25 e $30^{\circ} \mathrm{C}$. Sementes armazenadas por 12 meses a temperatura ambiente e a $4{ }^{\circ} \mathrm{C}$ foram colocadas para germinar nas condições ótimas e apresentaram germinabilidade e tempo médio de germinação similares à sementes recém-coletadas independente da temperatura de armazenamento, demonstrando potencial fisiológico para formação de banco de sementes. Os resultados sugerem que de forma similar às florestas tropicais, a luz pode ser um importante fator que controla o recrutamento de plântulas a partir do banco de sementes para espécies de sementes pequenas de cerradão.
\end{abstract}

Palavras chave: armazenamento, banco de semente, Cerrado, fotoblastismo, recrutamento

ABSTRACT - (Seed germination ecophysiology of the wild pineapple, Ananas ananassoides (Baker) L.B.Sm. (Bromeliaceae)). In this study we investigated the effects of light, temperature, and storage on seed germination of the wild pineapple Ananas ananassoides, an understorey species found in cerrado woodlands. Seeds were germinated at temperatures of 15, 20, 25, 30 and $35^{\circ} \mathrm{C}$ and a 12-hr photoperiod and continuous darkness for 30-d. Seeds were photoblastic and the optimum temperatures for germination were 25 and $30^{\circ} \mathrm{C}$. Seeds stored for 12 -mo at room temperature and at $4{ }^{\circ} \mathrm{C}$ were set to germinate at optimum conditions. Germinability of stored seeds did not differ from that of recently collected seeds, regardless of storage temperature, indicating their physiological potential for seed bank formation. Our results suggest that as in tropical rainforests, light may be an important factor controlling recruitment from seed banks for small-sized species from the cerrado woodlands.

Key words: Cerrado, photoblastism, recruitment, seed bank, seed storage

\section{Introduction}

The extensive studies of seed longevity and germination of tropical-forest species have highlighted the importance of temperature and light in germination control (VázquezYanes \& Orozco-Segovia 1993). Under a closed canopy and dense litter cover, light is prevented from reaching the forest soil surface, thus inhibiting germination of photoblastic seeds. Seeds of light-demanding species can cue for changes in light spectral quality and increases in diel (day-night) fluctuations of soil temperature following canopy opening, and thus germination is promoted (Pearson et al. 2003).

In contrast to several studies of regeneration in tropical rainforests, few studies exist on regeneration of savanna plant species. The forest/savanna boundary reflects not only a discontinuity in species composition but also differences in tree density (Hoffmann et al. 2003), resulting in higher light incidence and lower soil moisture in savannas. The Brazilian savanna (cerrado) comprises contrasting physiognomies ranging from open grasslands to nearly closed woodlands (cerradão), with a canopy $12-15 \mathrm{~m}$ high and crown cover of 50-90\% (Oliveira-Filho \& Ratter 2002). Grasslands have recently received attention regarding seed germination, which is not light-limited (Garcia \& Oliveira 2007). On the other hand, the canopy cover can prevent light from reaching the soil in the cerrado woodlands. Despite the marked floristic differences between rainforests and cerradão, they present similar vegetation structure, suggesting that environmental factors controlling seed germination may be similar. This study focused on the effects of light, temperature and storage on seed germination of a small-seeded understorey bromeliad from a closed woodland. We aimed to test light-dependence in seed germination and to determine their physiological longevity to be incorporated into seed banks.

\section{Material and methods}

The bromeliad Ananas ananassoides (Baker) L.B.Sm. is found in Neotropical savannas or inland low-shade forests, growing on soils with limited water-holding capacity and forming populations of variable densities. Regeneration of $A$. ananassoides populations can occur sexually (through seed production) and vegetatively (Coppens d'Eeckenbrugge \& Leal 2003). In May 2004, fruits $(n=50)$ were collected at a cerradão in the Pirapitinga Ecological Station (18 $23^{\prime}$ 'S; $45^{\circ} 20^{\prime} \mathrm{W}$ ) in Três Marias, Minas Gerais. The mean monthly annual temperature ranged from 21 to $25^{\circ} \mathrm{C}$, with an average annual precipitation of $1200 \mathrm{~mm}$ (F.A.O. Silveira et al., pers. com.).

Fruits were dissected and the seeds removed had their seed coats disinfected with $2 \%$ sodium hypochlorite followed by washing in running water. Seed weight (dry mass obtained after exposing seeds at $70^{\circ} \mathrm{C}$ for $120 \mathrm{~h}$ ) was determined by weighing four replicates of 25 seeds on a digital scale. Seeds were placed in Petri dishes ( 4 replicates of 25 seeds per treatment) covered with double sheets of filter paper and then incubated under $15,20,25,30$ and $35^{\circ} \mathrm{C}$ and a $12 \mathrm{~h}$-photoperiod (photon flux density $=25.86 \mu \mathrm{mol} \mathrm{m}^{-2} \mathrm{~s}^{-1}$ ) and continuous darkness for 30-d. Lots of recently-collected seeds were stored in a hermetically closed dark glass

\footnotetext{
Universidade Federal de Minas Gerais, Instituto de Ciências Biológicas, Ecologia Evolutiva \& Biodiversidade/DBG. Belo Horizonte, MG, Brazil

2 Universidade Federal de Uberlândia, Instituto de Biologia, Uberlândia, MG, Brazil

3 Author for correspondence: faosilveira@gmail.com
} 
for 12 months at $4{ }^{\circ} \mathrm{C}$ or ambient $\left(\sim 25^{\circ} \mathrm{C}\right)$ temperature. Stored seeds were set to germinate at $25^{\circ} \mathrm{C}$ and a $12 \mathrm{~h}$-photoperiod and complete darkness.

The Kruskal-Wallis test followed by the Conover test was used to determine differences among temperatures and the Mann-Whitney test was used to determine differences between light conditions at the same temperature $(\alpha=0.05)$. Mean germination time (MGT) was calculated following Labouriau (1983).

\section{Results and discussion}

The average weight of $A$. ananassoides seeds was 0.061 $\pm 0.01 \mathrm{~g}$. Temperature and light significantly affected the germination of recently collected seeds. Germinability was greater under light than under darkness at all tested temperatures, except at $15^{\circ} \mathrm{C}$ where values near zero were observed for both conditions (Tab. 1). Optimum temperatures for seed germination (highest germinability in less time) were 25 and $30^{\circ} \mathrm{C}$, with significant differences in germinability $(\mathrm{H}=17.27 ; p<0.001)$ and $\mathrm{MGT}(\mathrm{H}=12.29$; $p<0.006$; Tab. 1).

Studies focusing on light effects on germination of Bromeliaceae seeds have yielded contrasting results, with findings of negative, neutral, and positive effects (Mercier \& Guerreiro-Filho 1990; Rosa \& Ferreira 1998; Pinheiro \& Borghetti 2003; Garcia \& Oliveira 2007; Tarré et al. 2007; Vieira \& Silveira 2010). seeds of $A$. ananassoides are photoblastic and seed storage did not affect their photoblastism. Light effects on germination decrease with increasing seed size and are likely to be more closely related to seed size than to habitat (Fenner \& Thompson 2005).

Although the optimum temperature for seed germination ranges from $20{ }^{\circ} \mathrm{C}$ to $30{ }^{\circ} \mathrm{C}$ in bromeliads, temperature effects are associated with the environmental conditions where the species occur (Mercier \& GuerreiroFilho 1990; Pinheiro \& Borghetti 2003; Vieira et al. 2007; Vieira \& Silveira 2010). The negative effects on germinability caused by high temperatures seem to be widespread in bromeliads in different ecosystems, but since bromeliad species occupy a great diversity of habitats they might respond differently to temperature
(Mercier \& Guerreiro-Filho 1990, Rosa \& Ferreira 1998, but see Pinheiro \& Borghetti 2003).

The temperature of seed storage did not affect germinability $(\mathrm{H}=5.08 ; p=0.08)$. Germinability of seeds stored at all experimental conditions was over $90 \%$ under light. Furthermore, seed storage did not alter seed photoblastism irrespective of the storage temperature (Fig. 1), MGT was significantly lower in the $4{ }^{\circ} \mathrm{C}$ storage treatment compared to the other treatments $(\mathrm{H}=7.54 ; p=0.002$; Fig. 1$)$; thus suggesting that seed vigor was hardly affected by storage.

In our study, germinability of $A$. ananassoides was unaffected by seed storage temperature. Although low temperatures are preferred to reduce seed aging, many species can be stored at ambient temperature for long periods without significant viability losses (Schmidt 2000). Ananas ananassoides has small seeds that are similar to the seed size of typical pioneer species. Small seeds are usually photoblastic and easily buried, being more likely to have increased soil persistence (Fenner \& Thompson 2005). Our results suggest that $A$. ananassoides seeds are physiologically able to be incorporated into soil seed banks under closed canopy, such as those found in the "cerradão". However, because the conditions of artificial (ex situ) seed storage frequently do not match the natural conditions when seeds are in the soil (in situ storage), data should be viewed with caution. Available data on the germination and longevity of monocots from grasslands suggests that Bromeliaceae species do not maintain viability in the soil for over a 12-mo period and thus lack the potential to form persistent soil seed banks (Garcia \& Oliveira 2007). In situ storage experiments are needed to shed light on this issue. The high seed longevity of $A$. ananassoides under the tested storage temperatures has an important implication for seed conservation. Ex situ seed storage provides a supply of good quality seeds for planting programs whenever needed (Schmidt 2000), and has been recommended as an efficient conservation strategy of the biological and genetic diversity of wild plants (Tarré et al. 2007).

Table 1. Effect of light and temperature on germinability (\%) and mean germination time (days) of Ananas ananassoides seeds. Means are followed by standard deviation. Different uppercase letters represent statistically different means among temperatures and small case letters represent statistically different means between light and darkness conditions at the same temperature treatment.

\begin{tabular}{|c|c|c|c|c|}
\hline \multirow[t]{2}{*}{ Temperature $\left({ }^{\circ} \mathrm{C}\right)$} & \multicolumn{2}{|c|}{ Germinability (\%) } & \multicolumn{2}{|c|}{ Mean germination time (days) } \\
\hline & Light & Dark & Light & Dark \\
\hline 15 & $1 \pm 2 \mathrm{D}$ & 0 & 30 & $*$ \\
\hline 20 & $61 \pm 10 \mathrm{Ba}$ & $14 \pm 5,13 \mathrm{Ab}$ & $21,20 \pm 0,32 \mathrm{Aa}$ & $13,62 \pm 4,86 \mathrm{Bb}$ \\
\hline 25 & $93 \pm 2 \mathrm{Aa}$ & $17 \pm 8,86 \mathrm{Ab}$ & $16,71 \pm 0,33 \mathrm{Ba}$ & $21,62 \pm 1,34 \mathrm{Bb}$ \\
\hline 30 & $93 \pm 5,03 \mathrm{Aa}$ & $2 \pm 2,3 \mathrm{Bb}$ & $16,59 \pm 0,75 \mathrm{Ba}$ & $25,5 \pm 4,95 \mathrm{Ab}$ \\
\hline 35 & $40 \pm 5,65 \mathrm{C}$ & 0 & $19,01 \pm 0,89 \mathrm{~A}$ & $*$ \\
\hline
\end{tabular}

* Not calculated. 


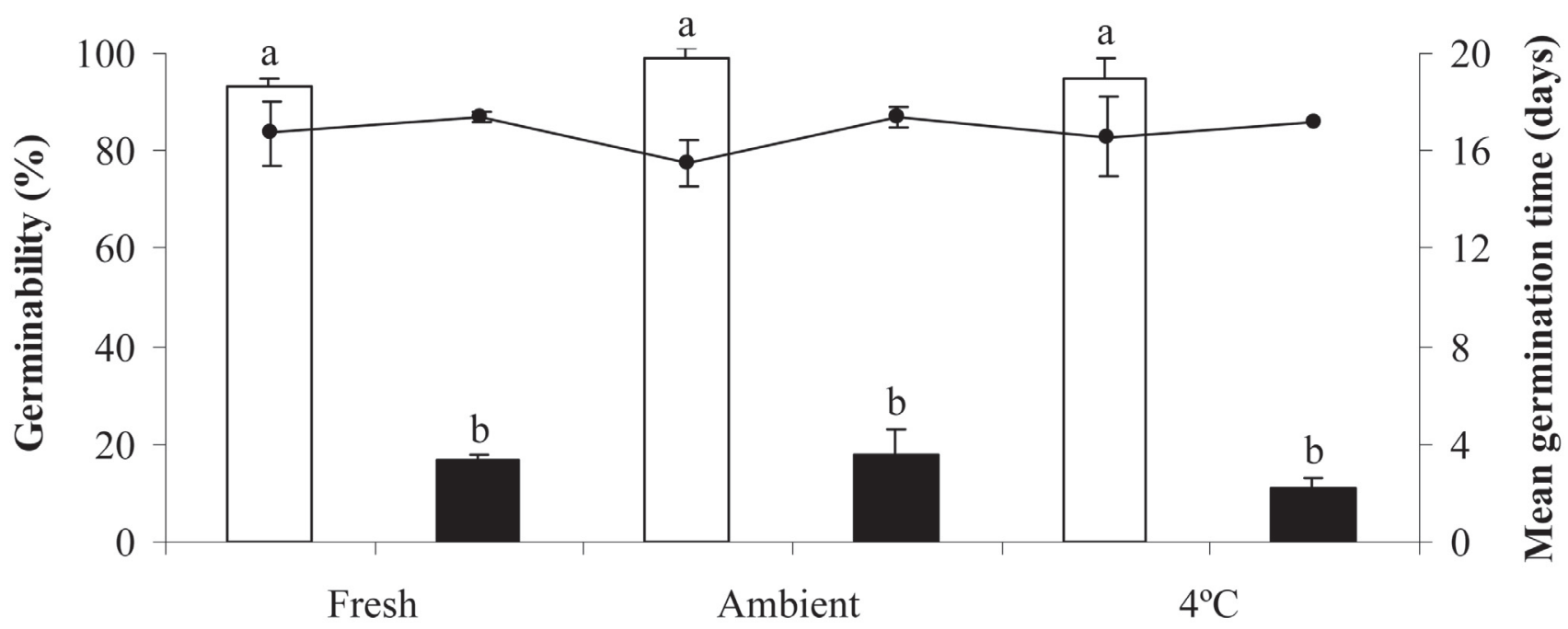

Storage treatments

Figure 1. Effect of seed storage treatment on germinability (bars) and mean germination time (line) of Ananas ananassoides seeds submitted to 12h-photoperiod (open bars) and complete darkness (full bars). Means are followed by standard deviation and different letters represent statistically different.

Light response is often associated with small seed sizes and provides information on the regeneration ecology of plant species. In the classical accounts of succession in tropical rainforests, small seed size has been associated with lightdemanders while large seed size has been associated with shade tolerance (Metcalfe et al. 1998). This model predicts that forest pioneer species with small photoblastic seeds have seed germination triggered by environmental changes following gap formation (Pearson et al. 2003). Consequently, these pioneer species colonize open areas, thereby improving the establishment of shade-tolerant species as succession progresses. The small-sized, long-lived, photoblastic seeds of $A$. ananassoides represent life-history traits of a pioneer species, but seedlings are absent from open areas (Coppens d' Eeckenbrugge \& Leal 2003), which can be related to fire intolerance and/or drought stress that reduces rates of seedling establishment, growth and survival.

In conclusion, the regeneration strategies of smallseeded species of "cerradão" can be similar to those of tropical forests. Under a closed canopy, vegetative reproduction of $A$. ananassoides may represent an alternative strategy for propagation in conditions of low germination. Consequently, the dynamics of gap formation may affect its spatial distribution and demography. We put forward that recruitment from seed takes place in open, litter-free sites whereas clonal reproduction occurs in shaded areas.

\section{Acknowledgments}

We thank M. Takaki, M.A.O. Fernandéz, R.A. Ball, P.R. Savard and A. Bernardino for suggestions and English corrections, the Instituto Chico Mendes de Conservação da Biodiversidade (Três Marias) for providing logistical support and D. Negreiros for help with figure editing. This project was supported by $\mathrm{CNPq}$ (47.2491/2003-2, 30.4851/2004-3, 14.0071/2003-2) and Fapemig (465/07).

\section{References}

Coppens d'Eeckenbrugge, G.C. \& Leal, F. 2003. Morphology, anatomy and taxonomy. Pp. 13-31. In: Bartholomew, D.P.; Paull, R.E. \& Rohrbach, K.G. (Ed.). The pineapple: botany, production and uses. New York, Cabi-Publishing.

Fenner, M. \& Thompson, K. 2005. The Ecology of Seeds. Cambridge, Cambridge University Press.

Garcia, Q.S. \& Oliveira, P.G. 2007. Germination patterns and seed longevity of monocotyledons from the Brazilian campos rupestres. Seed Science and Biotechnology 1: 35-41.

Hoffmann, W.A.; Orthen, B. \& Nascimento, P.K.V. 2003. Comparative fire ecology of tropical savanna and forest trees. Functional Ecology 17: $720-726$

Labouriau, L.G. 1983. A germinação das sementes. Washington, OEA.

Mercier, H. \& Guerreiro-Filho, O. 1990. Propagação sexuada de algumas bromélias nativas da Mata Atlântica: efeito da luz e da temperatura na germinação. Hoehnea 17: 19-26.

Metcalfe, D.J.; Grubbm P.J. \& Turner, I.M. 1998. The ecology of very small-seeded shade-tolerant trees and shrubs in lowland rain forest in Singapore. Plant Ecology 134: 131-149.

Oliveira-Filho, A.T. \& Ratter, J.A. 2002. Vegetation physiognomies and woody flora of the Cerrado Biome. Pp. 91-120. In: Oliveira, P.S. \& Marquis, R.J. (org.). The Cerrados of Brazil: ecology and natural history of a neotropical savanna. New York, Columbia University Press.

Pearson, T.R.H.; Burslem, D.F.R.P.; Mullins, C.E. \& Dalling, J.W. 2003. Functional significance of photoblastic germination in neotropical pioneer trees: a seed's eye view. Functional Ecology 17: 394-402.

Pinheiro, F. \& Borghetti, F. 2003. Light and temperature requirements for germination of seeds of Aechmea nudicaulis (L.) Griesebach and Streptocalyx floribundus (Martius ex Schultes F.) Mez (Bromeliaceae). Acta Botanica Brasilica 17: 27-35.

Rosa, S.G.T. \& Ferreira, A.G. 1998. Germinação de sementes de espécies medicinais do Rio Grande do Sul: Bromelia antiacantha Berth., Cuphea carthagenensis (Jacq.) Macbride. e Talinum patens (Jacq) Willdenow. Acta Botanica Brasilica 12: 515-522.

Schmidt, L. 2000. Guide to Handling of Tropical and Subtropical Forest Seed. Humlebaek, Danida Forest Seed Centre. 
Tarré, E.; Balzana, B.; Guimarães, A.P.M.; Carneiro, L.; Forzza, R.C. \& Mansur, E. 2007. Germinability after desiccation, storage and cryopreservation of seeds from endemic Encholirium Mart. ex Schult. \& Schult. f. and Dyckia Schult. \& Schult. f. species (Bromeliaceae). Acta Botanica Brasilica 21: 777-783.

Vázquez-Yanes, C. \& Orozco-Segovia. A. 1993. Patterns of seed longevity and germination in the tropical rain forest. Annual Review of Ecology and Systematics 24: 69-87.
Vieira, B.C. \& Silveira, F.A.O. 2010. Reproductive phenology, seed germination and ex situ conservation of Pseudananas sagenarius in a semi-deciduous tropical forest fragment. Plant Species Biology 25: $214-220$

Vieira, D.C.M.; Socolowski, F. \& Takaki, M. 2007. Germinação de sementes de Dyckia tuberosa (Vell.) Beer (Bromeliaceae) sob diferentes temperaturas em luz e escuro. Revista Brasileira de Botânica 30: 183-188.

Versão eletrônica do artigo em www.scielo.br/abb e http://www.botanica.org.br/acta/ojs 